\title{
The use of intestinal markers to measure digestive function in ruminants
}

\author{
By J. C. MAcRaE, Hill Farming Research Organization, Bush Estate, Penicuik, \\ Midlothian $\mathrm{EH} 26$ oPH
}

\section{Introduction}

The use of markers in nutrition has been extensively reviewed recently by Kotb \& Luckey (1972). The purpose of this paper is to evaluate the use of specific intestinal markers (hereafter called markers) in certain techniques now commonly used in ruminant nutrition studies.

Markers are used for one of two basic purposes: either to indicate the time taken for digesta to pass along the tract, from point $A$ to point $B$; or as inert reference substances whose concentration in digesta can be used to measure digestibilities, volumes, or $24 \mathrm{~h}$ flow rates. Kotb \& Luckey (1972) suggested that before a substance qualifies as an effective nutritional marker it should: (I) be inert with no toxic physiological or psychological effects; $(2)$ be neither absorbed nor metabolized within the gastrointestinal (GI) tract; (3) have no appreciable bulk; (4) mix intimately with and remain uniformly distributed in the digesta; (5) have no influence on GI secretion, digestion, absorption, or normal motility; (6) have no influence on the microflora of the GI tract; (7) have physico-chemical properties, readily discernible throughout the GI tract, which allow ready, precise, quantitative measurement.

Unfortunately, until recently, none of the substances employed as markers completely satisfied all these criteria and it was left to the judgement of an experimenter to select the material which most nearly met his requirements; those markers commonly selected for ruminant nutrition work are discussed below.

\section{Liquid-phase markers}

In the past, dyes have been used extensively as total digesta and liquid-phase markers (see Kotb \& Luckey, 1972), but currently their use for the latter purpose has been superseded by either polyethylene glycol (PEG) or the chromium ethylenediaminetetraacetic acid complex (Cr EDTA).

\section{$P E G$}

Between the mid-I950's, when Hydén (I955) developed a turbidimetric estimation procedure for PEG and showed that it could be used to study rumen volumes, and the mid-I960's, PEG was by far the most commonly used liquid-phase marker. However, although later modifications to the estimation procedure by Corbett, Greenhalgh, Gwynn \& Walker (1958) and Ulyatt (1964) reduced analytical error 
to some extent, it is still a laborious and non-specific method. Downes \& McDonald (1964) have since developed the use of radioactive ${ }^{51} \mathrm{Cr}$ EDTA, which to a large extent has replaced PEG in many studies. Till \& Downes (I965) suggested that ${ }^{3} \mathrm{H}-$ labelled PEG $\left({ }^{3} \mathrm{H}-\mathrm{PEG}\right)$ overcame the estimation difficulties and could be used as a satisfactory alternative while, more recently, Pickard \& Stevens (I972) have used ${ }^{14} \mathrm{C}$-labelled PEG in studies with rabbits. These preparations do not seem to have been used to any extent in ruminant studies, and indeed recently Neudoerffer, McLaughlin, Slinger \& Horney (1973) have reported dissatisfaction with ${ }^{3} \mathrm{H}-\mathrm{PEG}$ in cattle experiments because they found that it appeared to adhere to the particulate phase of digesta to some extent. Another limitation to the use of PEG with certain diets was reported by Kay (1969) when he found that with heather diets, PEG was precipitated out of solution, probably by the high concentration of tannic acid.

\section{Cr EDTA}

Where radioactive ${ }^{51} \mathrm{Cr}$ EDTA and ${ }^{3} \mathrm{H}-\mathrm{PEG}$ are used, small amounts of marker can be accurately measured, and both these radioactive isotopes can be detected in urine, suggesting that small amounts of both markers are absorbed from the tract. Downes \& McDonald (I964), Hogan (1964) and Weston \& Hogan (1967) showed that less than $5 \%$ of administered ${ }^{51} \mathrm{Cr}$ EDTA was so absorbed and suggested that appropriate corrections could be made. When continuously infusing ${ }^{51} \mathrm{Cr}$ EDTA to study the partition of digestion between the different regions of the GI tract, the Australian workers have assumed that half this absorption takes place from the stomach (Weston \& Hogan, ${ }_{19} 6_{7}$ ).

More recently Binnerts, van't Klooster \& Frens (1968) suggested that by using atomic absorption spectrophotometry, non-radioactive Cr EDTA can be accurately measured, thereby removing the problems of widespread use of radio-isotopes. Goodall \& Kay (1973) found that, in thirty-two comparisons, the rumen volume estimations obtained with non-radioactive Cr EDTA $(7 \cdot 96 \pm 0.13$ l) were greater than those measured with PEG $(6.9 \pm 0.13 \mathrm{l})$ and suggested that this difference could be accounted for to some extent by the fact that only $92 \%$ of the rumen water was available to PEG whereas $99 \%$ was available to Cr EDTA.

At the Hill Farming Research Organization (HFRO) we have satisfactorily used non-radioactive $\mathrm{Cr}$ EDTA for many rumen volume and digesta liquid-phase retention time studies in sheep given a variety of herbage diets; in these experiments $\mathrm{Cr}$ has been estimated by X-ray fluorescent spectrometry (Lazar \& Monson, 1965). As a result of these studies we have concluded that the method of preparing the nonradioactive complex is a matter of some importance and requires discussion.

Binnerts et al. (1968) prepared $\mathrm{Cr}$ EDTA by boiling $\mathrm{CrCl}_{3} \cdot 6 \mathrm{H}_{2} \mathrm{O}$ with excess $\mathrm{Na}_{2}$ EDTA, neutralizing the excess EDTA with $\mathrm{CaCl}_{2}$ and adjusting the $\mathrm{pH}$ to $6-7$ with alkali. On the other hand, Goodall \& Kay (1973) prepared their non-radioactive complex by boiling $\mathrm{Na}_{2} \mathrm{EDTA}$ with excess $\mathrm{CrCl}_{3} \cdot 6 \mathrm{H}_{2} \mathrm{O}$, and precipitating the excess $\mathrm{CrCl}_{3}$ by adjusting the $\mathrm{pH}$ to 7 with $\mathrm{NH}_{4} \mathrm{OH}$ (a scaled-up modification of the method of Downes \& McDonald (I964)). This latter method gives a complex in the 
presence of considerable amounts of $\mathrm{NH}_{4} \mathrm{Cl}$. When using such a preparation at HFRO to measure rumen volumes and $\mathrm{NH}_{3}$ concentrations in heather-fed sheep, addition of $100 \mathrm{ml}$ of the $\mathrm{Cr}$ EDTA (Coodall \& Kay suggest $200 \mathrm{ml}$ to be a suitable daily dose for this purpose) raised the rumen $\mathrm{NH}_{3}$ levels from 20-30 $\mathrm{mg} \mathrm{NH}_{3} /$, where no $\mathrm{Cr}$ EDTA was given, to $200-25^{\circ} \mathrm{mg} / \mathrm{l} 2 \mathrm{~h}$ after administration of the $\mathrm{Cr}$ EDTA. Thereafter the $\mathrm{NH}_{3}$ concentration fell steadily $(90-100 \mathrm{mg} / 1 \mathrm{I} 2 \mathrm{~h}$ after administration) until there was no detectable extra $\mathrm{NH}_{3}$ present in samples taken $22 \mathrm{~h}$ after administration; analysis showed that our Cr EDTA solution contained nearly $20 \mathrm{mg} \mathrm{NH} / \mathrm{ml}$. Such observations impose serious limitations to the use of this particular preparation, especially on poorer-quality, low-nitrogen diets. Amounts of the preparation given to sheep when the complex is isotopically labelled (Downes $\& \mathrm{McDonald}, \mathrm{I}$ 964) are much smaller and the $\mathrm{NH}_{3}$ present is probably nutritionally insignificant. The ${ }^{51} \mathrm{Cr}$ EDTA complex obtainable from the Radiochemical Centre, Amersham is prepared in an excess of $\mathrm{Na}_{2} \mathrm{EDTA}$ and adjusted to $\mathrm{pH} 3.5^{-4}$ with $\mathrm{NaOH}$ (W. H. Davies, Radiochemical Centre, personal communication); it contains no detectable $\mathrm{NH}_{3}$.

\section{Particulate-phase markers}

The use of either radioactive or inert Cr EDTA to indicate volumes, or movements of the digesta liquid phase, is unlikely to provide biased data. Unfortunately this cannot be said of the many particulate markers.

From several points of view lignin would be the ideal particulate marker. As an integral part of most ruminant diets, it fully satisfies criteria (1), (3), (4), (5) and (6) given above. Unfortunately, whilst it has been used in many studies in the past, it is not commonly used nowadays because of (a) the empirical nature of its determination, (b) its variable digestibility and (c) its apparent change in composition during passage through the GI tract, probably resulting from partial degradation (see Elam \& Davis, 196r; van Soest, 1964; Allison \& Osbourne, 1970).

The need is to find an external marker which will closely associate itself with the particulate phase of digesta during its passage through the tract. Unfortunately, of the many substances tried, it is doubtful if any were really adequate until the recent harnessing of certain rare-earth elements.

In early studies of rate of passage, many artificial particulates were used to monitor the solid phase of digesta. However, Hoelzel (1930) showed that in several single-stomached animals, and in himself, the rates of passage of markers such as cotton knots, glass beads, steel ball-bearings, and silver or gold wire were roughly inversely proportional to their specific gravity; as far as he could tell the heavier materials tended to be held back mainly in the hind-gut.

The findings of Hoelzel ( 1930 ) may not, of course, be wholly applicable to ruminants, but Balch \& Campling (I965) point out quite serious limitations to the use of markers such as stained natural or artificial particles and discs in studies with cows. They instanced the findings of Balch (1950) that the faecal excretion of stained ground-hay particles was more rapid than that of long-hay particles (an observation later fully supported by Ellis (I968) who labelled different-sized particles with 
radioactive cerium), and the findings of King \& Moore (1957) and Campling \& Freer (1962) that the specific gravity of particles $\left(1 \cdot 00-1^{\circ} 40\right)$ had considerable influence on their rate of passage. It is perhaps interesting to note that the relationship between specific gravity and rate of passage of these particles distal to the rumen was in fact similar to the observations of Hoelzel ( 1930 ).

\section{Chromium sesquioxide}

Chromium sesquioxide $\left(\mathrm{Cr}_{2} \mathrm{O}_{3}\right)$ is probably still the most commonly used marker in nutrition studies today. However the adequacy of this material depends to a large extent on the purpose for which it is used, and data now being obtained with the newer rare-earth particulate markers strongly support the previous contention that $\mathrm{Cr}_{2} \mathrm{O}_{3}$ does not associate itself closely with the solid phase of digesta. Consequently, in studies where this is of prime importance, the validity of using $\mathrm{Cr}_{2} \mathrm{O}_{3}$ must be questionable.

The use of $\mathrm{Cr}_{2} \mathrm{O}_{3}$ as a faecal output marker in digestibility or intake experiments does not require that the $\mathrm{Cr}_{2} \mathrm{O}_{3}$ be closely associated with the digesta particulate phase. The only requirement is that added $\mathrm{Cr}_{2} \mathrm{O}_{3}$ must be fully recovered and so as long as experiments are designed to allow for the appreciable diurnal (Elam, Putnam \& Davis, I959; Troelsen, I965; Faichney, I974) and daily (MacRae \& Armstrong, I969) variability of faecal $\mathrm{Cr}_{2} \mathrm{O}_{3}$ output, this marker can probably give satisfactory data.

Similarly, when $\mathrm{Cr}_{2} \mathrm{O}_{3}$ is used to correct observed $24 \mathrm{~h}$ flows of digesta obtained from re-entrant cannulas to average $24 \mathrm{~h}$ bases (MacRae \& Armstrong, r969) it is not imperative for the $\mathrm{Cr}_{2} \mathrm{O}_{3}$ to closely associate itself with the particulate phase of the digesta. The basic assumption with this technique is that, over any period, the flows of $\mathrm{Cr}_{2} \mathrm{O}_{3}$ and of the digesta constituents are affected to the same extent. This was shown to be valid when sheep were continuously fed on a dried-grass diet (MacRae, Ulyatt, Pearce \& Hendtlass, 1972). In ten duodenal and eleven ileal $24 \mathrm{~h}$ collections there were significant linear relationships $(P<0.0 \mathrm{I})$ between the observed flows of $\mathrm{Cr}_{2} \mathrm{O}_{3}$ and the observed flows of dry matter (DM), organic matter, $N$, cellulose, hemicellulose and gross energy, with the intercepts on the $y$ axis very nearly passing through the origin in all instances.

However, in studies of transit time of digesta or in techniques where digesta samples are obtained from animals prepared with $T$-shaped cannulas, experimenters have assumed that $\mathrm{Cr}_{2} \mathrm{O}_{3}$ passes through the $\mathrm{GI}$ tract at the same rate as the particulate phase of digesta and is closely associated with that phase. Data obtained over the last few years would suggest that these assumptions are not true and could lead to considerable error. These observations have been made using the rare-earth particulate markers.

\section{The rave-earth particulate markers}

At very low concentrations (below ro ${ }^{-11} \mathrm{M}$ ) rare earth elements exhibit 'radiocolloidal behaviour', i.e. strong adsorptive properties (Schweitzer \& Jackson, I 952). 
Workers in the USA were probably the first to apply these adherence properties to indigestible marker techniques. Ellis \& Ibert ( 1964 ) reported that when dysprosium was added to in vitro rumen incubations, over $95 \%$ adhered to the particulate phase in $15 \mathrm{~min}$, whilst in in vivo experiments they obtained quantitative faecal recovery of added marker. Dy was determined by activation analysis (Ellis, 1968).

The same group also followed up an earlier suggestion by Garner, Jones \& Ekman (1960) that radioactive cerium $\left({ }^{144} \mathrm{Ce}\right)$ could also be used as a particulate marker. Huston \& Ellis (Ig68) showed that ${ }^{144} \mathrm{Ce}$ absorbed onto hay particles did not appear to transfer to other particles during digestion, and Ellis \& Huston (I968) used ${ }^{144} \mathrm{Ce}$ adsorbed onto food particles of different sizes to support the earlier findings (Balch, I950) that size of particle had a direct influence on retention time; they suggested that ${ }^{144} \mathrm{Ce}$ had considerable advantages over $\mathrm{Dy}$ in its assay procedure.

Although not particularly hazardous, radioactive $\mathrm{Ce}$ has to be handled with caution because it is adsorbed on to glassware and has a relatively long half-life $(285 \mathrm{~d})$. Australian workers have since developed the phenanthroline complex of ${ }^{103} \mathrm{Ru}\left({ }^{103} \mathrm{Ru}-\mathrm{phen}\right.$ ) as a particulate marker (Tan, Weston \& Hogan, I97I). They reported that in twenty-six sheep experiments the faecal recovery of ${ }^{103} \mathrm{Ru}$-phen (introduced intraruminally) was $97.4 \pm \mathrm{x} .7 \%$, with only $0.13 \pm 0.08 \%$ detectable in urine. Between $54 \%$ (lucerne diet) and $70 \%$ (clover diet) of the ${ }^{103} \mathrm{Ru}$ activity could be centrifuged out of abomasal contents at $3000 \mathrm{~g}$, whilst $88 \%$ (clover) and $97 \%$ (lucerne) of the ${ }^{103} \mathrm{Ru}$ could be centrifuged down at i $2000 \mathrm{~g}$. At concentrations of up to $\mathrm{I} \cdot 5 \times 1 \mathrm{O}^{-5} \mathrm{M}$ the complex did not appear to affect the rumen microbiota. In recent experiments at HFRO, when duodenal contents from heather-fed sheep receiving ${ }^{103} \mathrm{Ru}$-phen plus ${ }^{51} \mathrm{Cr}$ EDTA were filtered under reduced pressure and the particulate fraction was then washed with $2-3$ vol. of distilled water, all the ${ }^{51} \mathrm{Cr}$ but only some $4 \%$ of the ${ }^{103} \mathrm{Ru}$ activity could be cletected in the filtrate (MacRae, Wilson \& Milne, unpublished results).

Tan et al. (197I) suggested that ${ }^{103} \mathrm{Ru}$-phen has advantages over ${ }^{144} \mathrm{Ce}$ in that its $40 \mathrm{~d}$ half-life, its non-adsorption onto glassware and its less hazardous nature make it more convenient for routine use. Also, because of the different energy emissions of ${ }^{103} \mathrm{Ru}$ and ${ }^{51} \mathrm{Cr}$, both can be counted simultaneously on multichannel $\gamma$-counters, thus allowing the simultaneous use of both markers ('dual-phase' marking) to differentiate between the liquid and particulate phases of digesta in transit time determinations and spot-sampling techniques.

\section{Application of the 'dual-phase' marker technique to ruminant physiology}

(a) Transit time of digesta. Bertoni \& Suttle (1973) and Faichney (1974), using ${ }^{103} \mathrm{Ru}$-phen plus ${ }^{51} \mathrm{Cr}$ EDTA, and Huston \& Ellis (I968), using ${ }^{144} \mathrm{Ce}$ plus PEG, have all shown that when these markers are either added to the diet or introduced intraruminally the faecal excretion of liquid-phase marker is more rapid than that of the particulate-phase marker. However, when MacRae, Reid, Dellow \& Wyburn (1973) introduced ${ }^{103} \mathrm{Ru}$-phen plus ${ }^{51} \mathrm{Cr}$ EDTA at the ileum, excretion rates of the two markers were similar, suggesting that passage of liquid and particulate phases 
through the hind-gut were identical. Faichney (I974) and Huston \& Ellis (I968) also showed that the faecal excretion of $\mathrm{Cr}_{2} \mathrm{O}_{3}$ was intermediate in nature between that of the adsorbed particulate marker and that of the liquid-phase marker. This is perhaps not surprising in view of earlier discussions on the influence of specific gravity on retention times (specific gravity of $\mathrm{Cr}_{2} \mathrm{O}_{3}, 5^{\cdot} \cdot 2$ ), but adds strong support to the suggestion that $\mathrm{Cr}_{2} \mathrm{O}_{3}$ is not a satisfactory marker for transit time measurements.

(b) Sampling from T-shaped cannulas. 'T'he Prospect group are now using ${ }^{103} \mathrm{Ru}-$ phen plus ${ }^{51} \mathrm{Cr}$ EDTA routinely to measure $24 \mathrm{~h}$ flows of digesta entering the small intestine of ruminants (e.g. Faichney \& Weston, 197r; Hogan \& Weston, 1971; Weston, I97I; Hogan, 1973). When MacRae \& Ulyatt (I972) compared $\mathrm{Cr}_{2} \mathrm{O}_{3}$-corrected $24 \mathrm{~h}$ flow data, obtained in continuous collections from re-entrant cannulated sheep, with ${ }^{103} \mathrm{Ru}-$ phen- ${ }^{51} \mathrm{Cr}$ EDTA-calculated flow data, obtained in spot-sampling procedures from sheep with both re-entrant and simple $\mathrm{T}$-shaped cannulas, they found no significant differences in either DM or liquid flows. They suggested that the greater variability associated with the latter technique (coefficient of variation $(\mathrm{CV})$ for $\mathrm{DM}$ flows $=10 \%$, compared to $5 \%$ for re-entrant collections), should be compensated for by making more observations, especially in sheep which were not fed continuously, where the $\mathrm{CV}$ was $14 \%$. Diurnal variations in duodenal DM and liquid flow rates and concentrations of ${ }^{103} \mathrm{Ru}$-phen, ${ }^{51} \mathrm{Cr}$ EDTA and PEG were all very small, but diurnal variation in $\mathrm{Cr}_{2} \mathrm{O}_{3}$ concentrations was considerable, there being a 2 -fold difference between the peak concentration of $4 \mathrm{mg} / \mathrm{g}$ DM at approximately 20.00 hours and the lowest concentration at $\mathrm{I} 2.00$ hours. This suggested that $\mathrm{Cr}_{2} \mathrm{O}_{3}$ did not closely associate itself with the particulate phase, and would limit its use in spot-sampling procedures. Faichney (1974) also condemned $\mathrm{Cr}_{2} \mathrm{O}_{3}$ as a spot-sampling marker for use with simple T-shaped cannulas when he reported that, on three of the four diets given, $\mathrm{Cr}_{2} \mathrm{O}_{3}$ marker gave significantly lower $(P<0.05)$ abomasal flow rates than those obtained using ${ }^{103} \mathrm{Ru}$-phen-${ }^{5} \mathrm{Cr}$ EDTA in the same samples. However, when Corse \& Sutton (197I) used $\mathrm{Cr}_{2} \mathrm{O}_{3}$ to calculate $24 \mathrm{~h}$ flow rates in continuous collections from re-entrant cannulas and in spot-sampling procedures from both re-entrant and $\mathrm{T}$-shaped cannulas, they found good agreement between the two techniques.

These apparently contradictory findings perhaps emphasize the difficulties of the spot-sampling procedure where, unlike continuous collections from re-entrants, in which total digesta is collected and sub-sampled, there is no certainty that the sample obtained is truly representative of digesta passing the point of sampling. Samples obtained where dual-phase markers have been employed can be used to illustrate this problem. If a sample obtained is truly representative of the total digesta, it must in theory contain identical amounts of both markers, expressed as percentages of their daily dose. In Fig. I, samples obtained from sheep given dried grass (MacRae \& Ulyatt, 1972) and heather (MacRae, Wilson \& Milne, unpublished results) have been examined in this way. The ${ }^{103} \mathrm{Ru}$-phen concentrations are plotted relative to the ${ }^{51} \mathrm{Cr}$ EDTA concentrations and, if the samples were truly representative, each would lie on the $45^{\circ}$ line. For some reason most of the duodenal samples 


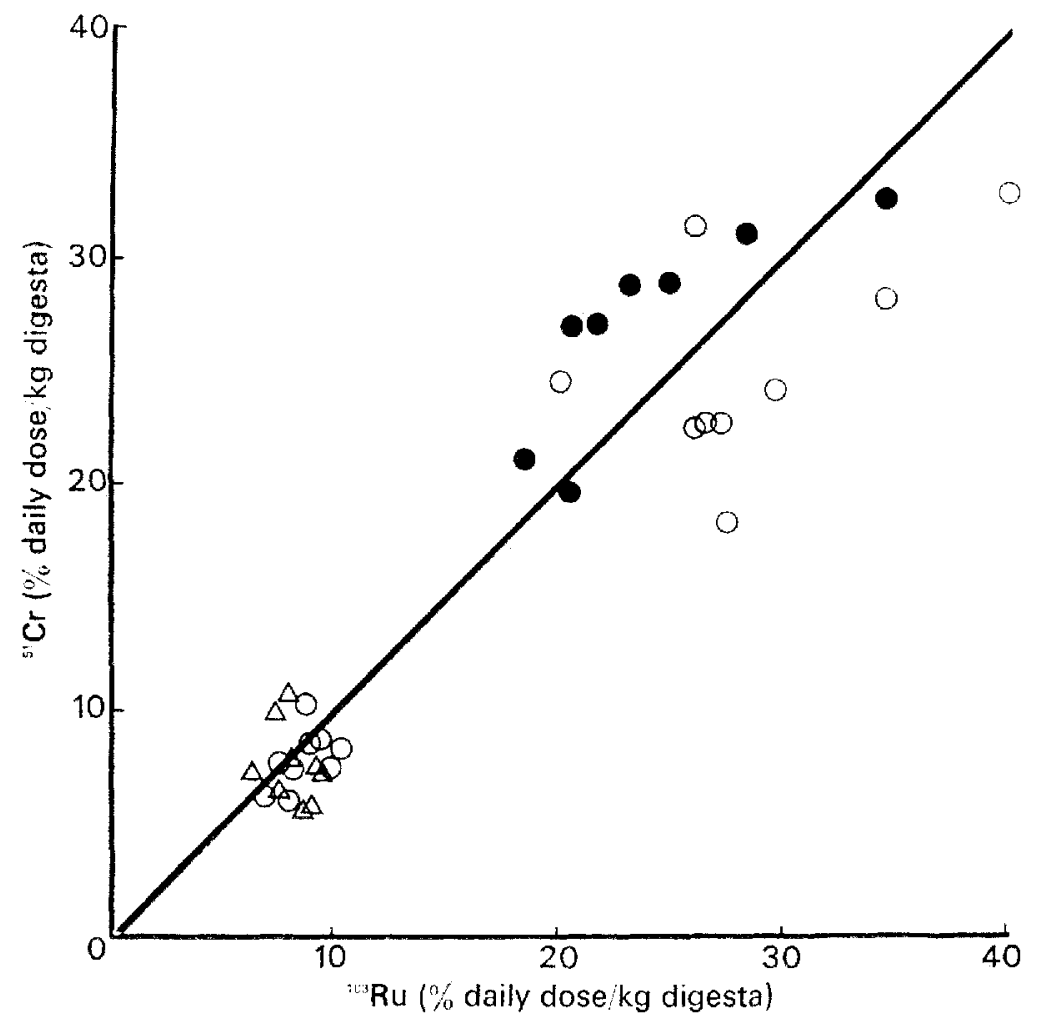

Fig. 1. Comparison of cnromium $\left({ }^{51} \mathrm{Cr}\right)$ and ruthenium $\left({ }^{103} \mathrm{Ru}\right)$ concentrations in spot-sampled digesta of sheep given dried grass and heather. Sampling by: $O$, duodenal T-shaped cannula; $\odot$, ilcal 'T-shaped cannula; $\Delta$, duodenal re-entrant cannula.

lie to the ${ }^{103} \mathrm{Ru}$ side of the line, while the converse is true for the ileal samples.

In these instances such sampling inadequacies can be overcome if $24 \mathrm{~h}$ flows of liquid and particulate phases and their constituents are calculated separately, i.c. relative to their ${ }^{51} \mathrm{Cr}$ and ${ }^{103} \mathrm{Ru}$ concentrations respectively. (This would be particularly important for constituents such as $\mathrm{N}$ and minerals; between $10 \%$ (heather diet) and $25 \%$ (dried-grass diet) of the total $\mathrm{N}$ in duodenal contents can be in the liquid phase.) However, in view of Fig. $x$, it is difficult to see how spot-sampling procedures carried out with single markers can give accurate data.

\section{Conclusions}

The author would strongly advocate the use of the newer particulate markers in preference to ones such as $\mathrm{Cr}_{2} \mathrm{O}_{3}$ or stained particles when carrying out transit time determinations or spot-sampling procedures and would suggest that 'dual-phase marker' systems such as ${ }^{103} \mathrm{Ru}$-phen- ${ }^{51} \mathrm{Cr}$ EDTA are likely to give the most meaningful results for the majority of studies. In particular, if dual-phase markers are used in spot-sampling procedures they are likely to provide a feasible alternative to the long-term automated collection techniques (Corse, 1974). 
Where facilities for use of radio-isotopes are not readily available the use of nonradioactive markers such as $\mathrm{Cr}$ EDTA, Dy (if activation analysis facilities are to hand) or inert Ru-phen (MacRae \& Evans, I974) could be examined. The dual-phase nonradioactive markers $\mathrm{Ru}-$ phen-- $\mathrm{Cr}$ ED'TA have been satisfactorily used in transit time studies at HFRO, but have not yet been employed as digesta sampling markers.

\section{RERERENCES}

Allison, D. W. \& Osbourne, D. F. (1970). F. agric. Sci., Camb. 74, 23.

Balch, C. C. (1950). Br. 7. Nutr. 4, 36r.

Balch, C. C. \& Campling, R. C. (1965). In Physiology of Digestion in the Ruminant p. 108 [R. W. Dougherty, editor]. Washington, DC: Butterworths.

Bertoni, G. \& Suttle, N. F. (1973). Riv. Zootec. Vet. I, 165.

Binnerts, W. 'T., van't Klooster, A. Th. \& Frens, A. M. (1968). Vet. Rec. 82, 470.

Campling, R. C. \& Freer, M. (1962). Br. F. Nutr. 16, 507.

Corbett, J. L., Greenhalgh, J. F. D., Gwynn, P. E. \& Walker, D. (1958). Br. F. Nutr. 12, 266.

Corse, D. A. (1974). Proc. Nutr. Soc. 33, I4I.

Corse, D. A. \& Sutton, J. D. (1971). Proc. Nutr. Soc. 30, 18A.

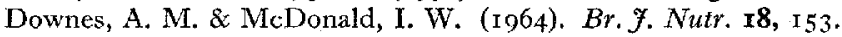

Elam, C. J. \& Davis, R. E. (I96I). Y. Anim. Sci. 20, 484.

Elam, C. J., Putnam, P. A. \& Davis, R. E. (1959). F. Anin. Sci. 18, 718.

Ellis, W. C. (1968). \%. agric. Fd Chem. 16, 220.

Ellis, W. C. \& Huston, J. E. (1968). Y. Nutr. 95, 67.

Ellis, W. C. \& Ibert, E. R. (1964). Proc. VIth int. Congr. Nutr., Edinburgh p. 575.

Faichney, G. J. (1974), Proc. IVth int. Symp. Ruminant Physiology (Session 5), Sydney.

Faichney, G. J. \& Weston, R. H. (I97I). Aust. F. agric. Res. 22, $46 \mathrm{I}$.

Garner, R. J., Jones, H. G. \& Ekman, L. (1960). F. agric. Sci., Camb. 55, 107.

Goodall, E. D. \& Kay, R. N. B. (1973). Proc. Nutr. Soc. 32, 22 A.

Hoelzel, F. (1930). Am. J. Physiol. 92, 466.

Hogan, J. P. (1964). Aust. F. agric. Res. 15, 384 .

Hogan, J. P. (1973). Aust. F. agric. Res. 24, 587.

Hogan, J. P. \& Weston, R. H. (1971). Aust. F. agric. Res. 22, 951.

Huston, J. E. \& Ellis, W. C. (1968). F. agric. Fd Chem. I6, 225.

Hydén, S. (1955). K. LantbrHögsk. Annlr 22, 139.

Kay, R. N. B. (1969). Proc. Nutr. Sac. 28, 22 A.

King, K. W. \& Moore, W. E. C. (1957). F. Dairy Sci. 40, 528 .

Kotb, A. R. \& Luckey, T. D. (1972). Nutr. Abstr. Rev. 42, 813.

Lazar, V. A. \& Monson, W. G. (x965). F. agric. Fd Chem. 13, i6r.

MacRae, J. C. \& Armstrong, D. G. (I969). Br. F. Nutr. 23, I 5 .

MacRae, J. C. \& Evans, C. C. (1974). Proc. Nutr. Soc. 33, 10A.

MacRae, J. C., Reid, C. S. W., Dellow, D. W. \& Wyburn, R. S. (1973). Res. vet. Sci. 14, 78.

MacRae, J. C. \& Llyatt, M. J. (1972). N.Z. Yl agric. Res. 15, 98.

MacRae, J. C., Ulyatt, M. J., Pearce, P. D. \& Hendtlass, J. (1972). Br. F. Nutr. 27, 39.

Neudoerffer, T. S., McLaughlin, D. R, Slinger, S. J. \& Horney, I. D. (1973). F. Anim. Sci. 36, 749.

Pickard, D. W. \& Stevens, C. E. (1972). Am. F. Physiol. 222, I 161.

Schweitzer, G. K. \& Jackson, M. (1952). F. chem. Educ. 29, 5 I3.

Tan, T. N., Weston, R. H. \& Hogan, J. P. (1971). Int. F. appl. Radiat. Isotopes 22, 30 .

Till, A. R. \& Downes, A. M. (1965). Br. F. Nutr. 19, 435.

Troelsen, J. E. (1965). Anim. Prod. 7, 239.

Ulyatt, M. J. (1964). N.Z. Yl agric. Res. 7, 7×3.

van Soest, P. J. (1964). J. Anim. Sci. 23, 838 .

Weston, R. H. (1971). Aust. \%. agric. Res. 22, 307.

Weston, R. H. \& Hogan, J. P. (1967). Aust. F. agric. Res. 18, 789. 